\title{
Three replacement names for species of the subfamily Leiinae (Diptera, Mycetophilidae)
}

\author{
Sarah Siqueira de Oliveira ${ }^{1} \&$ Dalton de Souza Amorim ${ }^{1,2}$
}

\begin{abstract}
${ }^{1}$ Universidade de São Paulo, Faculdade de Filosofia, Ciências e Letras de Ribeirão Preto, Departamento de Biologia, Avenida Bandeirantes 3900, 14040-901 Ribeirão Preto-SP, Brazil oliveira.sarahcv@gmail.com

${ }^{2} \mathrm{CNPq}$ Research Fellowship. dsamorim@usp.br
\end{abstract}

\begin{abstract}
Three replacement names for species of the subfamily Leiinae (Diptera, Mycetophilidae). New names are proposed for three cases of homonymy in the Mycetophilidae subfamily Leiinae, one in the genus Docosia Winnerz, one in Leia Meigen, and one in Tetragoneura Winnertz. Docosia garretti nom. nov. is proposed for Docosia setosa Garrett, 1925; Leia walkeri nom. nov. for Leia bimaculata (Walker, 1848); and Tetragoneura sasakawai nom. nov. for Tetragoneura tibialis Sasakawa, 1961. The context of each new name is discussed.
\end{abstract}

KEYWORDS. Docosia; homonymy; Leia; taxonomy; Tetragoneura.

RESUMO. Três novos nomes para espécies da subfamília Leiinae (Diptera, Mycetophilidae). Novos nomes são propostos para três casos de homonímia em Leiinae (Mycetophilidae), um no gênero Docosia Winnerz, um em Leia Meigen e um em Tetragoneura Winnertz. Docosia garretti nom. nov. é proposto para Docosia setosa Garrett, 1925; Leia walkeri nom. nov. para Leia bimaculata (Walker, 1848); Tetragoneura sasakawai nom. nov. para Tetragoneura tibialis Sasakawa, 1961. O contexto de cada nome novo é discutido.

PALAVRAS-CHAVE. Docosia; homonímia; Leia; taxonomia; Tetragoneura.

While revising the literature of the Neotropical Mycetophilidae towards the preparation of an updated catalogue for the family, we came across some species names from different regions in need of replacement in the genera Docosia Winnertz, Leia Meigen and Tetragoneura Winnertz. Here we propose new names for these species, with some additional comments.

\section{Docosia garretti, nom. nov.}

Replacement name for Docosia setosa Garrett, 1925: 12; not Docosia setosa Landrock, 1916: 63. Type-locality: Canada. British Columbia.

Etymology. This species is named after the Canadian dipterist Cecil B. D. Garrett (1882-1979), who contributed to the knowledge of taxonomy of the Mycetophilidae, mainly from the Nearctic.

Comments. Garrett (1925) proposed the name Docosia setosa for a species from British Columbia, Canada. This name was already used by Landrock (1916) for a species described from Czech Republik. In the catalogue of the Nearctic Mycetophilidae, Laffoon (1965) indicated that the name was preoccupied without proposing a replacement name.

\section{Leia walkeri, nom. nov.}

Replacement name for Leia bimaculata (Walker 1848: 100); not Leia bimaculata (Meigen 1804: 92). Type-locality: "East Indies".

Etymology. The species is named after the English dipterist Francis Walker (1809-1874). Besides his work on Diptera taxonomy, he also published catalogues of Orthoptera, Neuroptera, Homoptera, Lepidoptera and Hymenoptera.

Comments. The name Mycetophila bimaculata was used by Meigen (1804) for a species from Germany. The same name was proposed later by Walker (1848) for a species from "East Indies", possibly from India. Subsequently both species were moved to Leia. The Oriental catalogue of the Mycetophilidae (Colless \& Liepa 1973) did not recognize the homonymy with Meigen's (1804) species.

\section{Tetragoneura sasakawai, nom. nov.}

Replacement name for Tetragoneura tibialis Sasakawa 1961: 192; not Tetragoneura tibialis Freeman 1951: 86. Type-locality: Ambo-Funayki, Yakushima, Kyushu (Japan). Distr.: Japan.

Etymology. This species is named after the Japanese dipterist Mitsuhiro Sasakawa, who works on different 
dipteran families, especially Agromyzidae and some other acalyptrate groups.

Comments. Sasakawa (1961) proposed the name Tetragoneura tibialis for a species from Japan, not aware that the same name was used earlier by Freeman (1951) for a species described from Argentina (Rio Negro, Bariloche). Hackman et al. (1988) did not recognize that the name was preoccupied.

Further comments

It should also be noted that Fisher (1939: 234) described a species of Leiella under the name Leiella bicolor, which Papavero (1978: 31) mistakenly indicated that had been originally described as a species of Leia. Brunetti (1912: 100) described Leia bicolor from West Bengal, but in fact there is no need of a replacement name in this case.

Another case of homonymy in the Leiinae has already been solved. Leia fasciata Storå (1936: 10), described from the Canary Islands, is a homonym of Leia fasciata Kértesz (Kértesz 1902: 574), described from Peru, also present in Bolivia, Paraguay, Brazil, and Argentina (Papavero 1978). Hackman et al. (1988) did not recognize the homonymy. Later on, Chandler \& Ribeiro (1995) recognized Leia fasciata Storå as identical to Leia arsona Hutson (1978: 123), described from South Africa, St. Helena and Kenya, also present in a London infestation associated to rotting root-ginger. It is worth mentioning that Hutson (1978) pointed to a similarity between Leia arsona Hutson and Leia fasciata Kértesz. It was commented by Hutson (1978: 122) that L. arsona could be a species belonging to "a species-group that is mainly South American". One can not exclude the possibility that $L$. arsona is a Neotropical species later introduced to Africa. Besides, this species has become widely introduced in Europe and the Mediterranean region as well as in New Zealand (Toft \& Chandler 2004).

Acknowledgments. We are grateful to Eirik Rindal for his useful comments to our manuscript and to FAPESP for the financial support (Grants 2003/10.274-9 and 2008/52324-6).

\section{REFERENCES}

Brunetti, E. 1912. Diptera Nematocera (excluding Chironomidae and Culicidae). Fauna of British India (Diptera) 1: 1-581.

Chandler, P. J. \& E. Ribeiro. 1995. The Sciaroidea (Diptera) (excluding Sciaridae) of the Atlantic Islands (Canary Islands, Madeira and the Azores). Boletim do Museu Municipal do Funchal (HistóriaNatural), Suplemento Number 3: 1-170.

Colless, D. H. \& Z. Liepa. 1973. Superfamily Mycetophiloidea, family Mycetophilidae, p. 444-463. In: M. D. Delfinado \& D. E. Hardy (eds.) A catalog of the Diptera of the Oriental Region. Vol. 1. Honolulu, University Press of Hawaii. 618 p.

Fisher, E. G. 1939. Costa Rican Mycetophilidae (Diptera). Transactions of the American Entomological Society 65: 227-236.

Freeman, P. 1951. Diptera of Patagonia and South Chile based mainly on material in the British Museum (Natural History). Part III. Mycetophilidae. London, British Museum (Natural History). vii+138 p.

Garrett, C. B. D. 1925. Seventy new Diptera - key to the Pseudoleria, Helomyzidae, Tipulidae, Chironomidae, Dixinae, Orphnephilidae, Mycetophilidae. Privately published, Cranbrook. 16 p.

Hackman, W.; P. Laštovka; L. Matile \& R. Väisänen. 1988. Mycetophilidae, p. 220-327. In: Á. Soós \& L. Papp. (eds.). Catalogue of Palaearctic Diptera. Volume 3. Amsterdam Elsevier.

Hutson, A. M. 1978. An undescribed african species of Leia (Dipt. Mycetophilidae) infesting root-ginger in London. Entomologist's Monthly Magazine 113: 121-124.

Kertész, K. 1902. Neue Neoglaphyroptera-Arten aus Süd-Amerika. Természetrajzi Füzetek 25: 573-581.

Laffoon, J. L. 1965. Mycetophilidae, p. 196-229. In: A. Stone, C. W. Sabrosky; W. W. Wirth; R. H. Foote \& J. R. Coulson (eds.). A Catalog of the Diptera of America North of Mexico. Washington. Agricultural Research Service. United States Department of Agriculture.

Landrock, K. 1916. Neue mährische Arten der Pilzmückengattung Docosia Winn. Zeitschrift des Mährischen Landesmuseums 15: 59-66.

Meigen, J. W. 1804. Klassifikazion und Beschreibung der europäischen zweiflügeligen Insekten (Diptera Linn.). Erster Band. Abt. I. xxviii + p. 1-152, Abt. II. vi + p. 153-314. Reichard, Braunschweig [= Brunswick].

Papavero, N. 1978. Mycetophilidae, p. 1-78. In: N. Papavero (ed.). A Catalogue of the Diptera of the Americas South of the United States. Museu de Zoologia, Secretaria da Agricultura do Estado de São Paulo, São Paulo.

Sasakawa, M. \& N. Tamu. 1961. Japanese Fungivoridae (Diptera). III. New or little-known fungus gnats from the Tsushima Islands. The scientific report of Kyoto Prefectural University Human Environment and Agriculture 13: 68-69.

Storå, R. 1936. Fam. Mycetophilidae. In: R. Frey: Die Dipterenfauna der Kanarischen Inseln und ihre Probleme. Commentationes biologicae 6: $10-14$.

Toft, R. J. \& P. J. Chandler. 2004. Three introduced species of Mycetophilidae (Diptera: Sciaroidea) established in New Zealand. New Zealand Entomologist 27: 43-49.

Walker, F. 1848. List of the specimens of dipterous insects in the collection of the British Museum. Part 1. London. The Trustees, British Museum (Natural History), 229 p. 